Dr inż. arch. Adam Baryłka

Centrum Rzeczoznawstwa Budowlanego Sp. z o.o., Warszawa

\title{
ZAGADNIENIE ZDATNOŚCI OBIEKTÓW BUDOWLANYCH DO UŻYTKOWANIA W PROBLEMATYCE INŻYNIERII BEZPIECZEŃSTWA TYCH OBIEKTÓW
}

\section{Streszczenie}

Podczas okresowych kontroli dokonuje się sprawdzenia stanu technicznego i oceny przydatności obiektu budowlanego do dalszego bezpiecznego użytkowania poprzez:

- zidentyfikowanie symptomów zużycia technicznego obiektu oraz

- oszacowanie wpływu tego zużycia na właściwości użytkowe i sprawność techniczną obiektu budowlanego.

W referacie zaproponowano ocenę stanu technicznego obiektów budowlanych bazującą na logice czterowartościowej.

\section{Summary}

During periodic inspections, the technical condition and assessment of the suitability of the building object for further safe use are checked by:

- identification of symptoms of technical wear of the facility and

- estimation of the impact of this consumption on the functional properties and technical efficiency of the building.

The paper proposes an assessment of the technical condition of buildings based on a fourvalued logic.

\section{Wprowadzenie}

Przedmiotem zainteresowania niniejszego opracowania są obiekty budowlane, które są projektowane, budowane i eksploatowane dla zaspokojenia różnorodnych potrzeb człowieka. Wypełniają one najliczniej środowisko, w którym funkcjonuje człowiek i zgodnie z pracami [2-5] determinują w długim okresie ich istnienia warunki bezpieczeństwa życia człowieka.

Obiekty budowlane $\mathrm{w}$ procesie eksploatacji tracą swoje własności cech użytkowych w wyniku oddziaływania na nie różnych czynników wewnętrznych i zewnętrznych. W większości przypadków oddziaływania te mają charakter niekorzystny i po pewnym czasie prowadzą do utraty własności użytkowych obiektu budowlanego. Dlatego właściciel (zarządca) obiektu budowlanego w procesie jego eksploatacji powinien podejmować działania minimalizujące skutki tych oddziaływań poddając obiekt budowlany procesowi odnowy.

Jednym $\mathrm{z}$ początkowych etapów realizacji procesu odnowy eksploatowanych obiektów budowlanych są okresowe kontrole stanowiące pierwszy etap diagnostyki technicznej stanów eksploatowanego obiektu budowlanego. Etap ten określa czynności związane z identyfikowaniem stanów technicznych w użytkowanym obiekcie dla zaistniałego zbioru zdarzeń lub sytuacji eksploatacyjnych.

Podczas okresowych kontroli dokonuje się sprawdzenia stanu technicznego i oceny przydatności obiektu budowlanego do dalszego bezpiecznego użytkowania poprzez:

- zidentyfikowanie symptomów zużycia technicznego obiektu oraz

- oszacowanie wpływu tego zużycia na właściwości użytkowe i sprawność techniczną obiektu budowlanego. 
W referacie zaproponowano metodę oceny stanu technicznego obiektów budowlanych, bazującą na logice czterowartościowej, stosowanej w ocenie stanu obiektów technicznych.

\section{Zagadnienie zmiany stanu obiektu budowlanego}

Wiedza na temat istoty zmiany stanu obiektu budowlanego (w okresie przewidywanego jego istnienia) dotycząca fizykochemicznych oraz technicznych aspektów procesów starzenia i zużycia materiałów i konstrukcji obiektów budowlanych jest niezbędna w rozwiązywaniu większości zagadnień ich projektowania, konstruowania, wytwarzania i eksploatacji. Pozwala

ona na racjonalne postępowanie w ww. zakresie, w tym wybór odpowiedniej technologii wytwarzania oraz optymalizację właściwości eksploatacyjnych złożonych konstrukcji różnych obiektów budowlanych.

Procesy starzenia i zużycia są nieodłącznie związane $\mathrm{z}$ istnieniem obiektów budowlanych, wpływając destrukcyjnie na ich stan techniczny i prowadząc nieuchronnie do ich degradacji wyrażającej się powstaniem i rozwojem dających się obserwować różnego rodzaju uszkodzeń, które mogą powodować przerwanie poprawności funkcjonowania konstrukcji, a nawet utratę fizycznej postaci obiektu.

W technicznym znaczeniu degradacja obiektu budowlanego jest związana $z$ fizykochemicznymi zmianami tego obiektu na skutek jego użytkowania, i jest wynikiem procesu pogarszania właściwości wytrzymałościowych i użytkowych poszczególnych elementów obiektu, a tym samym całego obiektu budowlanego. Następuje zarówno w wyniku ich intensywnej eksploatacji jak i agresywnego oddziaływania środowiska - stanowiących dwa podstawowe czynniki sprzyjające przedwczesnemu zużywaniu się obiektu budowlanego. W potocznym rozumieniu degradacja obiektu budowlanego jest utożsamiana z:

- pojęciem starzenia się obiektu budowlanego - nierozerwalnie zawiązanym ze znacznym upływem czasu eksploatacji oraz

- wpływem wszystkich czynników egzogennych tworzących środowisko funkcjonowania obiektu budowlanego.

W rzeczywistości degradacja obiektu budowlanego jest procesem bardziej złożonym, bowiem zależy ona nie tylko od wpływów eksploatacyjnych ale i od kumulowania się skutków

różnych procesów takich, jak: zużycie zmęczeniowe, pęknięcie, ścierne, odkształceniowe i pełzaniowe. Każdy z tych procesów związany jest nierozerwalnie z procesami projektowania, realizacji i eksploatacji obiektu budowlanego, w szczególności ze zmianą obciążenia zewnętrznego przenoszonego przez obiekt budowlany w procesie jego eksploatacji.

\section{Problem oceny stanu technicznego obiektu budowlanego}

\subsection{Stosowane metody oceny}

Jak wynika z prac [2-5] nie ma ujednoliconych zasad formułowania ocen stanu technicznego, konstrukcji i elementów konstrukcji obiektów budowlanych, są one różnie przyjmowane i charakteryzują się różnym poziomem uogólnienia, co rodzi szereg problemów związanych z wykorzystaniem efektów diagnostyki technicznej tych obiektów. Ocena stanu technicznego, konstrukcji lub elementów konstrukcji, jest wynikiem zakwalifikowania badanej konstrukcji lub jej elementu do grupy adekwatnej z parametrami i właściwościami do standardów opisujących dany stan (grupę).

$\mathrm{W}$ procesie diagnozowania stanu technicznego obiektów budowlanych wiadomo, że im większa będzie liczba rozróżnianych stanów obiektu, tym pozyskana informacja o obiekcie będzie bardziej wiarygodna. Problem prowadzenie wielowartościowego 
klasyfikowania stanów technicznych obiektów, a tym samym diagnozowania wielowartościowego, chociaż obecnie możliwe do zrealizowania, wymaga głębokich analiz technicznych i ekonomicznych. Celowość stosowania diagnozowania wielowartościowego obiektów technicznych różnych klas wymaga oddzielnych uzasadnień technicznoekonomicznych.

Aktualnie najczęściej korzysta się opisu tych stanów, według tzw. logiki: dwuwartościowej, trójwartościowej oraz czterowartościowej:

\section{1) Logika dwuwartościowa}

Zgodnie z pracami $[6,21]$ najczęściej korzysta się z opisu tych stanów według tzw. logiki dwuwartościowej, przyjmującej, że obiekty budowlane $\mathrm{w}$ procesie użytkowania mogą znajdować się w jednym z dwóch (wzajemnie wykluczających się) stanów technicznych:

- stanie zdatności (1), gdy obiekt zgodnie z przeznaczeniem realizuje funkcję celu;

- stanie niezdatności (0), gdy obiekt nie realizuje funkcji celu.

Dwuwartościowe klasyfikowanie stanów obiektów budowlanych powoduje, że w procesie ich diagnozowania wykorzystuje się tylko część możliwej do pozyskania informacji diagnostycznej. Ten rodzaj klasyfikacji diagnostycznej jest właściwy dla procesów techniczno-technologicznych oraz dla obiektów technicznych naprawialnych i nienaprawialnych. Celem tego rodzaju diagnozowania jest rozpoznanie stanu niezdatności (awarii) i zlokalizowanie elementu generującego taki stan. W przypadku organizacji działań obsługowych ważne znaczenie ma rozpoznanie w obiekcie stanów uprzedzających bezpośrednio wystąpienie stanu niezdatności, jakim jest stan zdatności niepelnej. Zastosowanie więc logiki dwuwartościowej na potrzeby organizacji procesu obsługiwania jest niewystarczające.

\section{1) Logika trójwartościowa}

Aby zwiększyć ilość informacji diagnostycznej uzyskanej podczas diagnozowania obiektu budowlanego w diagnostyce zaczęto stosować logikę trójwartościową rozwijaną w pracy [21]. Trójwartościowe klasyfikowanie stanów technicznych obiektu narzuca automatycznie stosowanie logiki trójwartościowej $(0,1,2)$ przyjmującej, że obiekty budowlane w procesie użytkowania mogą znajdować się w jednym z trzech (wzajemnie wykluczających się) stanów technicznych:

- stanie zdatności (2) do użytkowania, gdy obiekt budowlany realizuje funkcję celu, zgodnie z jego przeznaczeniem;

- stanie niepelnej zdatności (1) do użytkowania, gdy obiekt realizuje z ograniczeniami funkcję celu zgodną z jego przeznaczeniem;

- $\quad$ stanie niezdatności (0) do użytkowania, gdy obiekt nie jest w stanie realizować funkcji celu zgodnie z jego przeznaczeniem.

Wprowadzenie dodatkowego stanu pozwala na zwiększenie możliwej do uzyskania informacji diagnostycznej, co w kontekście eksploatacyjnych obsługiwań technicznych wspomaga ten proces oraz dodatkowo zwiększa również wartość przeciętnego czasu bezawaryjnej pracy obiektu. Wypracowane w ten sposób diagnozy stosowane są głównie w procesie lokalizowania uszkodzeń obiektu technicznego.

Pomimo, że problematyka diagnozowania w logice trójwartościowej jest obecnie intensywnie rozwijana to opracowane zagadnienia i reguły wnioskowania diagnostycznego nie w pełni rozwiązują problemy współczesnych obiektów technicznych. Ich duża złożoność i odpowiedzialność zadań wymaga dostarczenia użytkownikowi szybkiej i wiarygodnej informacji o stanie technicznym tych obiektów. Jednym ze sposobów przeciwdziałania powyższym problemom jest wprowadzenie diagnostyki wielowartościowej z większą liczbą stanów.

\section{2) Logika czterowartościowa}


W celu doprecyzowania procesu diagnozowania stanu technicznego obiektów technicznych, w pracy [6] wprowadzono opis stanu tych obiektów w tzw. logice czterowartościowej $(0,1,2,3)$, która podobnie jak logika trójwartościowa jest szczególnym przypadkiem logiki nwartościowej. Charakteryzuje się ona tym, że jej funkcje i argumenty mogą przyjmować jedną z czterech wartości określanych przez symbole $0,1,2,3$. Podobnie jak dla logiki dwu i trójwartościowej, obszar określoności dowolnej funkcji czterowartościowej jest ograniczony. W logice czterowartościowej wyróżnia się:

- stan zdatności obiektu (3), określa taki stan obiektu, w którym realizuje on zadania zgodnie z przeznaczeniem, przy założeniu, że wartości cech sygnałów wejściowych znajdują się w przedziałach zmian dopuszczalnych $\mathbf{X}_{\mathbf{j}}$. W tym stanie obiektu wartości cech sygnału $\mathbf{Y}_{\mathbf{i}}$ mieszczą się $\mathrm{w}$ przedziale nazwanym przedziałem zmian nieistotnych.

- stan niepełnej zdatności (2), określa stan obiektu posiadającego zdolność do niepełnego wykonania zadania, przy założeniu, że sygnały wejściowe znajdują się w przedziałach zmian dopuszczalnych wartości cech sygnałów $\mathbf{X}_{\mathbf{j}}$. W tym stanie zmiana wartości przynajmniej jednej cechy sygnału $\mathbf{Y}_{\mathbf{i}}$ musi mieścić się $\mathrm{W}$ przedziale nazwanym przedziałem zmian istotnych;

- stan zdatności krytycznej (1) określa stan obiektu charakteryzujący się zdolnością do wypełniania niektórych lecz nie wszystkich jego funkcji, przy założeniu, że sygnały wejściowe znajdują się w przedziałach zmian dopuszczalnych wartości cech sygnałów $\mathbf{X}_{\mathbf{j}}$. W tym stanie zmiana wartości przynajmniej jednej cechy sygnału $\mathbf{Y}_{\mathbf{i}}$ musi mieścić się $\mathrm{W}$ przedziale nazwanym przedziałem zmian krytycznych oraz

- stan niezdatności obiektu (0) określa stan obiektu posiadającego całkowitą niezdolność do wykonywania swoich zadań, przy założeniu, że sygnały wejściowe znajdują się w przedziałach zmian dopuszczalnych wartości cech sygnałów $\mathbf{X}_{\mathbf{j}}$. W tym stanie zmiana wartości przynajmniej jednej cechy sygnału $\mathbf{Y}_{\mathbf{i}}$ musi mieścić się $\mathrm{W}$ przedziale nazwanym przedziałem zmian niedopuszczalnych.

$\mathrm{Na}$ podstawie schematu klasyfikacji stanów obiektu w logice czterowartościowej przedstawionej na rys. 1 przyjęto następujące założenia:

- przejścia obiektu ze stanu "3" do stanu "2", ze stanu "2" do stanu "1" i ze stanu "1" do stanu "0" występują z jednakowym prawdopodobieństwem,

- jednoczesne wystąpienie stanów niezdatności i stanu zdatności krytycznej lub stanu niepełnej zdatności i stanu zdatności krytycznej elementów podstawowych obiektów technicznych wynosi poniżej 0,1

- obiekt może znajdować się w danym czasie t tylko w jednym z czterech stanów: "3", "2", "1" lub "0",

- $\quad$ stany zdatności, niepełnej zdatności i zdatności krytycznej należą do przedziału zmian dopuszczalnych co pozwala zachować zgodność z logiką dwu i trójwartościową. 


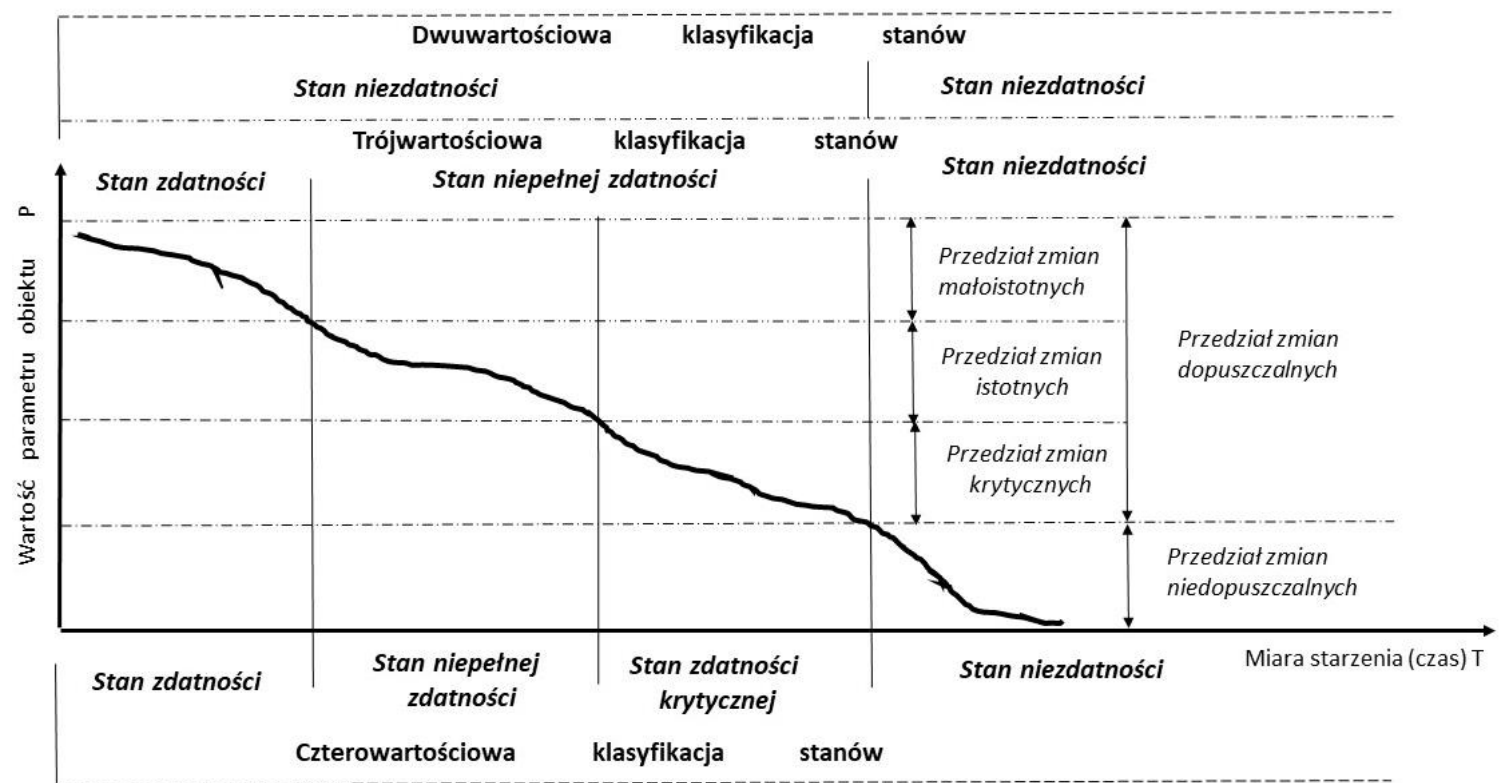

Rys. 1. Schemat klasyfikacji stanów obiektu budowlanego w logice czterowartościowej, w stosunku do klasyfikacji w logice dwu i trójwartościowej - według [6].

Wprowadzenie, w logice czterowartościowej, dodatkowego stanu charakteryzującego obiekt technicznych oprócz zwiększenia dostępnej informacji diagnostycznej powoduje również zwiększenie zakresu przedziału zmian istotnych. Rozpoznanie jednego ze stanów częściowej lub krytycznej zdatności, należących do tego przedziału, powinno skutkować podjęciem decyzji o przeprowadzeniu profilaktycznej odnowy technicznej. Działanie to ma na celu doprowadzenie eksploatowanego obiektu technicznego ponownie do stanu zdatności, czyli do przedziału zmian nieistotnych.

Model czterostanowy z dodatkowym stanem krytycznej zdatności określa stan obiektu zdolnego do wypełniania niektórych lecz nie wszystkich jego funkcji, przy założeniu, że sygnały wejściowe znajdują się w przedziałach zmian dopuszczalnych. Wprowadzenie dodatkowego stanu charakteryzującego obiekt technicznych oprócz zwiększenia dostępnej informacji diagnostycznej powoduje również zwiększenie zakresu przedziału zmian istotnych. Rozpoznanie jednego ze stanów częściowej lub krytycznej zdatności, należących do tego przedziału, powinno skutkować podjęciem decyzji o przeprowadzeniu profilaktycznej odnowy technicznej. Działanie to ma na celu doprowadzenie eksploatowanego obiektu technicznego ponownie do stanu zdatności, czyli do przedziału zmian nieistotnych.

\subsection{Propozycja wykorzystania logiki czterowartościową do diagnozowania stanu technicznego obiektów budowlanych}

Wykorzystując logikę czterowartościową do diagnozowania stanu technicznego obiektów budowlanych przedstawiam propozycję ogólnych opisów ww. stanów (które powinny być ustalane stosownie do specyfiki rozwiązania funkcjonalnego i materiałowokonstrukcyjnego danego obiektu budowlanego):

1) Stan zdatności obiektu budowlanego (3), jest to taki stan, w którym obiekt posiada pełną zdolność do wykonywania swoich zadań zgodnie z jego przeznaczeniem, czyli posiada wymagane dla danego obiektu budowlanego właściwości techniczne i użytkowe.

W takim stanie parametry techniczne i parametry użytkowe obiektu charakteryzujące właściwości związane $\mathrm{z}$ wymaganiami podstawowymi oraz właściwości użytkowe wynikające 
$\mathrm{z}$ przeznaczenia obiektu mieszczą się $\mathrm{w}$ przedziale wartości dopuszczalnych nawet $\mathrm{w}$ przypadku wystąpienia w obiekcie budowlanym zmian wynikających z uszkodzeń elementów (konstrukcyjnych, niekonstrukcyjnych i instalacyjnych), takich które jednak nie zagrażają bezpieczeństwu użytkowania.

Zatem obiekt budowlany w stanie zdatności to obiekt, który posiada wymagane (dla danego przeznaczenia) właściwości techniczne i użytkowe. Utrzymuje on te właściwości nawet w przypadku zmian zaistniałych $\mathrm{w}$ wyniku nieistotnych dla bezpieczeństwa uszkodzeń ww. elementów obiektu budowlanego i jest przydatny do określonego bezpiecznego użytkowania.

2) Stan niepełnej zdatności obiektu budowlanego (2), jest to taki stan, w którym obiekt posiada ograniczoną zdolność do wykonania przeznaczonych mu zadań, czyli posiada pogorszone, w stosunku do wymaganych dla danego obiektu budowlanego, właściwości techniczne i użytkowe wynikające $\mathrm{z}$ uszkodzeń elementów (konstrukcyjnych, niekonstrukcyjnych i instalacyjnych), które mogą utrudniać lub uniemożliwiać bezpieczne użytkowanie obiektu.

W takim stanie przynajmniej wartość jednego z parametrów (technicznych lub użytkowych) obiektu charakteryzujących właściwości związane $z$ wymaganiami podstawowymi oraz właściwości użytkowe wynikające z przeznaczenia obiektu wykracza poza przedział wartości dopuszczalnych i mieści się w przedziale nazwanym przedzialem zmian istotnych. Przy obniżeniu wartości cech technicznych i użytkowych obiektu budowlanego do wielkości minimalnych (granicznych) jest konieczne podejmowanie robot budowlanych o charakterze remontowym polegających na przywracaniu tym obiektom pierwotnych wartości tych cech.

W takim przypadku dla zapewnienia bezpiecznego użytkowania jest konieczne zastosowanie odpowiednich środków zaradczych, polegających między innymi na:

- wprowadzeniu ograniczeń w sposobie użytkowania obiektu budowlanego, polegających na zmniejszeniu intensywności użytkowania, zmiany sposobu użytkowania, które zmniejsza wielkość obciążeń, przekazywanych na konstrukcję, itp., oraz

- podjęciu czynności profilaktycznych ukierunkowanych na odnowę obiektu polegającą na przywróceniu pierwotnych parametrów technicznych i parametrów użytkowych obiektu.

(zgodnie z ustaleniami normy PN-ISO 15686-1: 2005 Budynki i budowle. Planowanie okresu użytkowania. Część 1: Zasady ogólne - „remont stanowi przywrócenie budynkowi lub jego części stanu możliwego do zaakceptowania poprzez odnowienie, wymianę lub naprawe elementów zużytych, lub które uległy degradacji”).

3) Stan krytycznej zdatności obiektu budowlanego (1), to stan, w którym obiekt budowlany znalazł się w stanie zagrożenia granicznego nośności lub użytkowalności, w którym określone parametry (techniczne lub użytkowe) osiągnęły wartości uznane za niedopuszczalne ze względów technicznych, funkcjonalnych i (lub) ekonomicznych. Jest to taki stan, w którym obiekt nie posiada zdolności do wykonania pełnego zakresu przeznaczonych mu zadań, czyli ma niedopuszczalne, w stosunku do wymaganych dla danego obiektu budowlanego, właściwości techniczne i użytkowe wynikające $\mathrm{z}$ uszkodzeń elementów (konstrukcyjnych,

niekonstrukcyjnych i instalacyjnych), które ograniczają możliwość bezpiecznego użytkowania obiektu.

Zagrożenie wystąpienia stanów granicznych nośności oraz stanów granicznych przydatności do użytkowania może dotyczyć poszczególnych elementów lub całości konstrukcji obiektu budowlanego może przejawiać się wystąpieniem stanu zagrożenia awarią budowlaną (lub stanu awarii budowlanej) lub stanu zagrożenia katastrofą budowlaną. Zewnętrznymi objawami osiągnięcia przez konstrukcję obiektu budowlanego stanów granicznych jest powstawanie uszkodzeń stanowiących zewnętrzne objawy stanu zagrożenia bezpieczeństwa 
obiektów budowlanych, takich jak: odkształcenia, deformacje, rysy i pęknięcia konstrukcji oraz elementów obiektu przylegających do konstrukcji.

Określenie stan graniczny oznacza tu taką sytuację w konstrukcji, że nawet nieznaczne zwiększenie obciążeń dyskwalifikuje ją $\mathrm{z}$ punktu widzenia stawianych wymagań. Po przekroczeniu stanu granicznego obiekt nie może być użytkowany na skutek braku fizycznych

możliwości funkcjonowania albo w wyniku decyzji o wyłączeniu z użytkowania.

Obiekt budowlany w stanie krytycznej zdatności do użytkowania wymaga:

1) maksymalnego ograniczenia jego użytkowania lub zaprzestania użytkowania, w celu zmniejszenia wielkości obciążeń przekazywanych na konstrukcję oraz

2) podjęcia czynności zabezpieczających obiekt budowlany, które zgodnie z por. pkt 2 rozdziału 9 obejmują, w zależności od potrzeb:

- prowizoryczne (czasowe) podparcie wychylonych elementów konstrukcji pionowych (ścian, słupów),

- prowizoryczne (czasowe) wzmocnienia innych elementów konstrukcji;

- rozebranie fragmentów obiektu zagrażających bezpieczeństwu lub rozebranie całości

obiektu budowlanego,

- ogrodzenie obiektu uniemożliwiającego dostęp do strefy zagrożenia,

- zmiany odwodnienia terenu.

4) Stan niezdatności obiektu budowlanego (0), jest to taki stan, w którym obiekt posiada całkowitą niezdolność do wykonywania swoich zadań, zgodnie z przewidywanym dla tego obiektu przeznaczeniem. To stan, w którym obiekt budowlany przekroczył stan graniczny nośności konstrukcji lub stan graniczny użytkowania, w którym określone parametry (techniczne lub użytkowe) osiągnęły wartości uznane za niedopuszczalne ze względów technicznych, funkcjonalnych i (lub) ekonomicznych. Jest to stan wynikający ze zniszczeń elementów (konstrukcyjnych, niekonstrukcyjnych i instalacyjnych), które uniemożliwiają bezpieczne użytkowanie obiektu. W takim stanie obiekt może przejść w każdej chwili w stan katastrofy budowlanej w związku ze zniszczeniem poszczególnych elementów lub całości obiektu budowlanego. Zagadnienie stanów granicznych konstrukcji obiektu budowlanego omówiono w punkcie 10.1.1 rozdziału 3 na podstawie normy PN-EN 1900:2004P.

\section{Stany techniczne obiektu budowlanego}

Jak wynika $\mathrm{z}$ rys. 2 obiekt budowlany poddawany w procesie jego eksploatacji różnorodnym oddziaływaniom wynikającym z przyczyn $\mathrm{P}(\mathrm{t})$ może znaleźć się $\mathrm{w}$ jednym $\mathrm{z}$ czterech niżej wymienionych stanów:

1) Stan zdatności, do którego należą:

- $S_{\mathrm{b} 1}$ - obiekt nieuszkodzony w stanie zdatności do bezpiecznego użytkowania;

- $\quad S_{\mathrm{ub} 1}$ - obiekt w stanie uszkodzenia, który nie zagraża bezpieczeństwu;

2) Stan niepelnej zdatności, do którego należą:

- $S_{\mathrm{ub} 2}$ - obiekt w stanie uszkodzenia, który nie zagraża bezpieczeństwu i jest zdatny do bezpiecznego użytkowania;

- $\mathrm{S}_{\mathrm{uz} 1}$ - obiekt w stanie uszkodzenia, który zagraża bezpieczeństwu;

3) Stan zdatności krytycznej, do którego należy:

- $\mathrm{S}_{\mathrm{uz2}}$ - obiekt $\mathrm{w}$ stanie granicznym nośności, który zagraża bezpieczeństwu niezdatny do użytkowania, zgodnie $\mathrm{z}$ jego przeznaczeniem;

- $\mathrm{S}_{\mathrm{uz} 3}$ - obiekt $\mathrm{w}$ stanie granicznym użytkowalności, który zagraża bezpieczeństwu niezdatny do użytkowania, zgodnie z jego przeznaczeniem;

4) Stan niezdatności, do którego należy: 
- $\mathrm{S}_{\mathrm{z} 1}$ - obiekt $\mathrm{w}$ stanie przekroczenia stanów granicznych nośności lub użytkowalności niezdatny do użytkowania

- $\quad \mathrm{S}_{\mathrm{z2}}$ - obiekt w stanie zniszczenia niezdatny do użytkowania;

- $\mathrm{S}_{\mathrm{z} 3}$ - obiekt w stanie katastrofy budowlanej niezdatny do użytkowania.

Zdarzenie zniszczenia obiektu budowlanego może być uznane za katastrofę budowlaną, jeżeli spełnia ono kryteria definicji katastrofy budowlanej zawarte w art. 73 ustawy - Prawo budowlane. Z danych GUNB wynika, że w latach 1995-2017 (23 lata) zaistniało w kraju 7669 katastrof budowlanych (średnio 333 katastrofy/rok).

Możliwości zmiany stanu obiektu budowlanego podanego uszkodzeniom $\mathbf{u}(\mathrm{t})$ oraz zniszczeniom $\mathbf{z}(\mathrm{t})$ wywołanym przyczynami technicznymi $\mathbf{P}(\mathrm{t})$, pochodzenia wewnętrznego i zewnętrznego zilustrowano na rys. 2 .

$\mathrm{Z}$ ww. rysunku wynika, że: obiekt znajdujący się $\mathbf{w}$ stanie zdatności $\mathbf{S}_{\mathbf{b}}$ do bezpiecznego użytkowania po upływie czasu może znajdować się w stanie nieuszkodzonym zdatnym do bezpiecznego użytkowania i wymagającym tylko podejmowania czynności konserwacyjnych utrzymujących jego cechy techniczno-użytkowe na wymaganym poziomie lub przejść:

- w stan uszkodzenia $S_{\mathrm{ub}}$, który nie zagraża bezpieczeństwu,

- w stan uszkodzenia $S_{\mathrm{uz}}$, który zagraża bezpieczeństwu oraz

- bezpośrednio w stan zniszczenia $S_{z}$ bez przechodzenia przez stany ww. uszkodzenia.

2) obiekt znajdujący się $\mathbf{w}$ stanie uszkodzenia $S_{\mathbf{u b}}$, który nie zagraża bezpieczeństwu może przejść:

- w stan uszkodzenia $S_{u b 1}$, zdatny do bezpiecznego użytkowania bezpieczeństwu,

- w stan uszkodzenia $S_{\text {ub2 } 2}$ niepełnej zdatności do bezpiecznego użytkowania,

- w stan uszkodzenia $S_{\mathrm{uz}}$, które zagraża bezpieczeństwu oraz

- bezpośrednio w stan zniszczenia $S_{z}$;

3) obiekt znajdujący się $\mathbf{w}$ stanie uszkodzenia $\mathbf{S}_{\mathbf{u z}}$, który zagraża bezpieczeństwu może przejść:

- w stan uszkodzenia $S_{\text {uzl }}$ o ograniczonej zdatności do bezpiecznego użytkowania,

- w stan krytycznej zdatności do bezpiecznego użytkowania $S_{\mathrm{uz} 2} \mathrm{~W}$ związku z osiągnięciem stanu granicznego nośności,

- w stan krytycznej zdatności do bezpiecznego użytkowania $S_{\mathrm{uz3}} \mathrm{W}$ związku z osiągnięciem stanu granicznego użytkowalności,

- bezpośrednio w stan zniszczenia $S_{z}$;

4) obiekt znajdujący się $\mathbf{w}$ stanie zniszczenia $S_{z}$, który zagraża bezpieczeństwu może przejść w stan niezdatności do bezpiecznego użytkowania:

- $\quad$ stan $S_{z 1}$ wyrażający się przekroczeniem stanów granicznych nośności lub użytkowalności,

- $\quad \operatorname{stan} S_{z 2}$ wyrażający się zniszczeniem obiektu lub jego części oraz

- $\quad$ stan $S_{z 3}$ wyrażający się katastrofa obiektu lub jego części. 


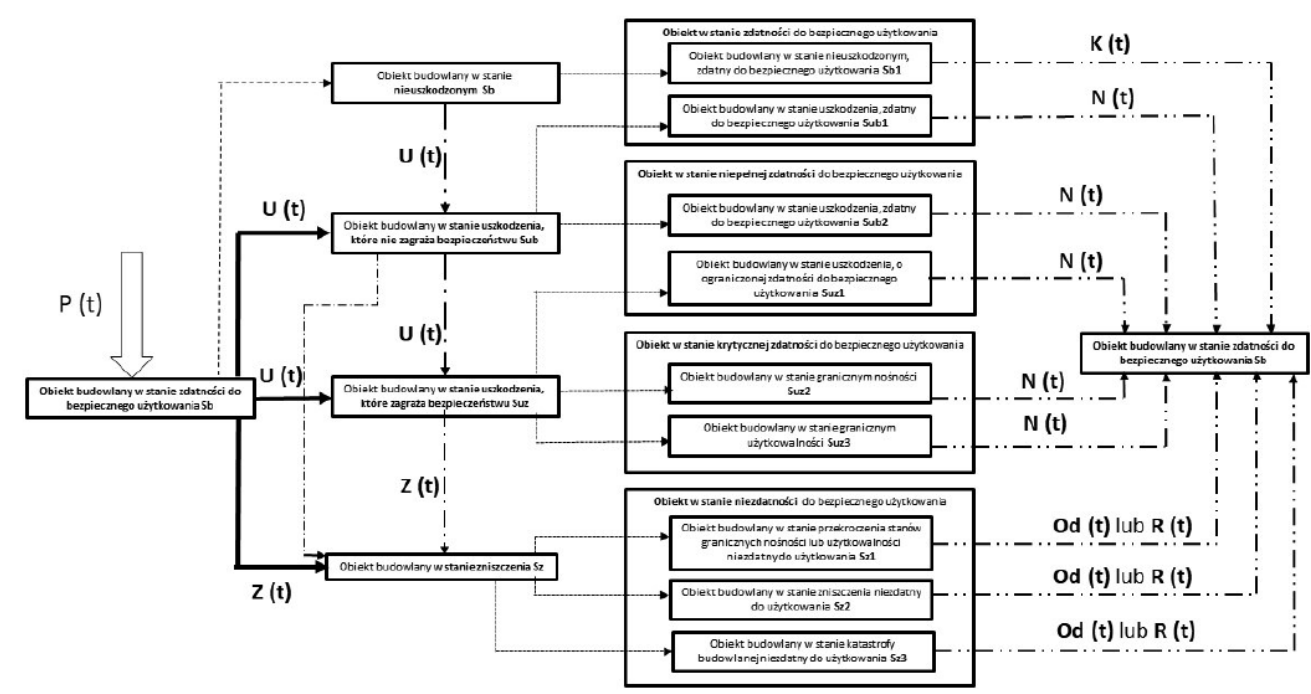

Rys. 2. Schemat poglądowy ilustrujący stany obiektu budowlanego wynikające ze zużycia technicznego charakteryzowanego przez zdarzenia uszkodzenia i zniszczenia jego elementów. $\mathrm{P}(\mathrm{t})$ - przyczyny techniczne zmiany stanu obiektu budowlanego,

$\mathrm{U}(\mathrm{t})$ - uszkodzenia wywołane przyczynami pochodzenia wewnętrznego i zewnętrznego, $\mathrm{Z}(\mathrm{t})$ - zniszczenia wywołane przyczynami pochodzenia wewnętrznego i zewnętrznego, $\mathrm{K}(\mathrm{t})$ - proces konserwacji, $\mathrm{N}(\mathrm{t})$ - proces naprawy (obejmujący działania remontowe), $\operatorname{Od}(\mathrm{t})$ - proces odbudowy obiektu, $\mathrm{R}(\mathrm{t})$ - proces rozbiórki obiektu

\section{Podsumowanie}

1) Nie ma ujednoliconych zasad formułowania ocen stanu technicznego konstrukcji i elementów konstrukcji eksploatowanych obiektów budowlanych, są one różnie przyjmowane i charakteryzują się różnym poziomem uogólnienia co powoduje określone problemy z wykorzystaniem wyników kontroli tych obiektów budowlanych.

2) W diagnostyce technicznej obiektu budowlanego za bardzo ważne należy uznać:

- działania zmierzające do wiarygodnego ustalenia stanu technicznego danego obiektu oraz możliwości jego dalszego bezpiecznego użytkowania oraz

- ocenę wpływu powstałych uszkodzeń i zniszczeń obiektu lub jego części na możliwość bezpiecznego użytkowania obiektu lub jego części;

3) Uwarunkowania bezpieczeństwa i ekonomiki eksploatacji obiektów budowlanych są przyczynami doskonalenia stosowanych metod oceny ich stanu technicznego oraz poszukiwania nowych metod oceny ich stanu technicznego.

4) Konieczność wiarygodności ustalenia stanu technicznego danego obiektu i możliwości jego dalszego bezpiecznego użytkowania wynika $\mathrm{z}$ potrzeby bezpieczeństwa obiektu budowlanego oraz uwarunkowań ekonomicznych.

5) Diagnoza stanu technicznego obiektu, uwzględniająca przyczyny powstania uszkodzeń i zniszczeń i przewidywany dalszy czas użytkowania jest podstawą racjonalnej oceny możliwości i celowości naprawy konstrukcji obiektu.

6) W przypadku stwierdzenia stanu zagrożenia bezpieczeństwa obiektu budowlanego niezbędne jest podjęcie przez właściciela (zarządcę) pilnych działań zmierzających do usunięcia występujących uszkodzeń i zniszczeń obiektu lub jego części wpływających na stan tego zagrożenia.

7) Brak działań naprawczych może doprowadzić obiekt budowlany lub jego część do stanu zniszczenia (katastrofy budowlanej). 


\section{Literatura}

1. Adamkiewicz A., Wstęp do racjonalnego wykorzystania urządzeń technicznych. WKi屯, Warszawa 1982.

2. Baryłka A., Baryłka J., Eksploatacja obiektów budowlanych. wyd. CRB, Warszawa, 2016.

3. Baryłka A., Okresowe kontrole obiektów budowlanych w procesie ich eksploatacji. wyd. 1 CRB, Warszawa, 2016 i wyd. 2 Warszawa 2018.

4. Baryłka A., Poradnik rzeczoznawcy budowlanego. Część I. Problemy technicznoprawne diagnostyki obiektów budowlanych. wyd. CRB, Warszawa, 2018.

5. Baryłka A., Poradnik rzeczoznawcy budowlanego. Część II. Problemy technicznoprawne diagnostyki posadowienia obiektów budowlanych. wyd. CRB, Warszawa, 2019.

6. Bernatowicz D., Duer S., Czterowartościowa logika stanów w diagnostyce złożonych obiektów technicznych. Logistyka nr 3, 2014.

7. Będkowski L., Dąbrowski T., Podstawy eksploatacji, część I Podstawy diagnostyki technicznej. Warszawa, 2000.

8. Będkowski L., Dąbrowski T., Podstawy eksploatacji, część II Podstawy niezawodności eksploatacyjnej. Warszawa, 2006.

9. Będkowski L., Elementy diagnostyki technicznej, WAT, Warszawa 1991.

10. Bojarski W., Wprowadzenie do oceny niezawodności działania układów technicznych. PWN, Warszawa 1967.

11. Bucior J., Podstawy teorii $i$ inżynierii niezawodności, Oficyna Wydawnicza Politechniki Rzeszowskiej, Rzeszów, 2004.

12. Bobrowski D., Modele i metody matematyczne teorii niezawodności w przykładach $i$ zadaniach. WNT, Warszawa, 1985.

13. Duer S., Wnioskowanie diagnostyczne o stanie obiektu technicznego $w$ logice $k$ wartościowej. Biuletyn WAT, nr 1, 2007.

14. Fokin J. D., Niezawodność eksploatacyjna urządzeń technicznych. MON, Warszawa, 1973.

15. Grądzki R., Lindstedt P., Metoda oceny stanu zdatności obiektu technicznego w otoczeniu warunków użytkowania $i$ obstugi. Wyd. Polskie Naukowo Techniczne Towarzystwo Eksploatacyjne, vol. 17, nr 1, Warszawa, 2015.

16. Jachowicz T. Wybrane zagadnienia niezawodności obiektów technicznych. Przetwórstwo tworzyw, nr 2 (marzec-kwiecień), 2009.

17. Jaźwiński J, Żurek J. Modelowanie $i$ identyfikacja systemu „Człowiek-obiekt techniczny-otoczenie $w$ aspekcie jego niezawodności $i$ gotowości. XIV Zimowa Szkoła Niezawodności PAN „Człowiek-obiekt techniczny-otoczenie. Problemy niezawodności i utrzymania ruchu". Szczyrk 1986.

18. Kuliś E., Żółtowski B., Zdatność zadaniowa pojazdów. Czasopismo naukowotechniczne, Postępy w inżynierii mechanicznej vol. 1, no.1(1), 2013.

19. Macha E., Niezawodność maszyn. Wyd. Politechnika Opolska, Opole 2001.

20. Migdalski J. (red.), Poradnik niezawodności. Podstawy matematyczne. Wyd. WEMA, Warszawa, 1982.

21. Migdalski J., Inżynieria niezawodności. Poradnik. t. 2. Wyd. Zetom, Warszawa,, 1992.

22. Miller D., Więcek A., Wybrane problemy diagnozowania trójwartościowego. MECHANIK XVII Międzynarodowa Szkoła Komputerowego Wspomagania Projektowania, Wytwarzania i Eksploatacji. Nr 7, 2013.

23. Nowogońska B., Ocena potrzeb remontowych na podstawie okresów trwatości elementów budynku, Przegląd Budowlany, nr 02, 2005.

24. Olearczuk E., Eksploatacja budynków mieszkalnych - problemy, prawidłowości, 
postępowanie, Wydawnictwo i Zakład Poligrafii, Instytutu Technologii Eksploatacji, Warszawa, 1999.

25. Olearczuk E., Eksploatacja nieruchomości budynkowych. Poradnik zarzadcy. Wyd.COIB, Warszawa, 2005.

26. Smalko Z., Podstawy projektowania niezwodnych maszyn urządzeń mechanicznych. Wyd. PWN, Warszawa, 1972.

27. Tymiński M., Tymińska M/., Zużycie społeczne obiektu mieszkalnego a problem modernizacji - aspekt ekonomiczny. Finanse, Rynki Finansowe, Ubezpieczenia nr 5, 2017.

28. Rut J., Wołczański T., Wybrane zagadnienia technicznych systemów zabezpieczeń obiektów. red. I. Mulicka, Opole: Oficyna Wydawnicza Politechniki Opolskiej, Opole 2014, Studia i Monografie, Politechnika Opolska z. 385, 2014.

29. Żółtowski B., Żółtowski M., Doskonalenie strategii utrzymania zdatności maszyn. Journal of KONBiN 4(20), 2011. 